\title{
ECOLOGICAL AND COENOTICAL STRUCTURE OF THE REGIONAL NATURAL MONUMENT «CHELYABINSK CITY PINE FOREST» VEGETATION
}

(C) 2019

\author{
Nazarenko Nazar Nikolayevich, doctor of biological sciences, \\ professor of Chemistry, Ecology and Chemistry Methodology Department \\ Novgorodova Maria Dmitrievna, student of Natural Sciences and Technologies Faculty \\ South Ural State Humanitarian Pedagogical University (Chelyabinsk, Russian Federation)
}

Abstract. The following paper deals with the ecological and coenotical structure of the Regional Natural Monument «Chelyabinsk city pine forest» vegetation. The estimation was done by a cluster analysis with SorensenChekanovsky (Bray-Curtis) distance measure and a flexible beta group linkage method - by non-metric multidimensional scaling, phytoindication and general discriminant analysis algorithms. The flora and coenotical structure of Chelyabinsk city pine forest plant communities are characterized by significant anthropogenic transformation. Forest-margin and meadow, ruderal and synanthropic species are insinuating and naturalizing in pine forest communities actively and supplanting typical pine forest species off communities. The studied pine forest flora synanthropic index is 32 percent. 15 plant associations were detected; its flora, dominant and constant species, coenotical structure and biotopes were characterized by principal ecological factors. The biotopes series of ecological factors replacement were identified. Biotopes series are specified by forest stand ecological structure, that determining ecological regime changes from semi-light to semi-shade and from more arid to more damp. Also biotopes form series from wet more variable moistening bad-aerated not-acid and salt enriched soils to acid aerated poor soils with contrast arid moistening. The detected Chelyabinsk city pine forest biotopes are characterized by not so fluctuation of principal ecological factors.

Keywords: classification of vegetation; ordination of vegetation; coenotical structure; synanthropization; phytoindication; numerical ecology; multidimensional scaling; discriminant analysis; biotopes; abiotic factors; Chelyabinsk city pine forest; Chelyabinsk Region; belt pine forests of South Ural.

УДК 595.768.12

DOI $10.24411 / 2309-4370-2019-12108$

Статья поступила в редакцию 09.01.2019

\section{ПРИЧИНЫ СОКРАЩЕНИЯ ЧИСЛЕННОСТИ НАСЕКОМЫХ САМАРСКОЙ ОБЛАСТИ (НА ПРИМЕРЕ ПОПУЛЯЦИЙ ЖУКОВ-ЛИСТОЕДОВ)}

(C) 2019

\section{Павлов Сергей Иванович, кандидат биологических наук,}

доцент кафедры биологии, экологии и методики обучения

Яицкий Андрей Степанович, старший преподаватель кафедры биологии, экологии и методики обучения

Самарский государственный социально-педагогический университет (2. Самара, Российская Федерация)

Минияров Фарит Талгатович, кандидат биологических наук, доцент кафедры

биотехнологии, зоологии и аквакультуры, заведующий лабораторией экспериментальной зоологии Астраханский государственный университет (2. Астрахань, Российская Федерация)

Аннотацияя. В течение 1974-2016 гг. в условиях Самарской области изучались механизмы выживания жуков-листоедов (как типичных насекомых-фитофагов) в окружении «агрессивной среды»: нестабильного, резко меняющегося климата, «убывающей» кормовой базы, прямого действия хищников, экто- и эндопаразитов, паразитоидов, возбудителей гельминтозов и энтомофторозов, других патогенных организмов. В качестве «модельных» объектов использовались 25 фоновых видов жуков-хризомелид (240 особей). Помимо закономерной пульсации численности насекомых (флуктуаций), выявлена 21 причина внезапных «скачков» численности местных популяций листоедов, в результате влияния на них негативных факторов среды, в том числе, абиотических (8), биотических (12) и антропогенных (1 причина). В результате неблагоприятных условий зимовки, резких колебаний температуры и влажности воздуха, ветра и осадков погибает от 5 до $90 \%$ популяции листоедов; 2 причины (касающиеся ресурсов кормовой базы), 2 причины (вызванные разбалансированностью возрастной и половой структуры популяции и потому низким репродуктивным потенциалом), 2 причины (определяемые жесткой конкуренцией насекомых и личиночным каннибализмом) и 6 причин (связанных с влиянием хищников, паразитов и возбудителей болезней) способны «изымать»еще от 2 до 96\% поголовья (яиц, личинок, куколок и имаго) особей популяции. Делается вывод о суммарном влиянии многих факторов на популяцию, что, несомненно, отрицательно влияет на численность насекомых.

Ключевые слова: Самарская область; листоеды; жуки-листоеды; насекомые-вредители; колебания численности; закономерные колебания численности; незакономерные колебания численности; абиотические факторы; биотические факторы; антропогенные факторы; энтомофаги; паразитические членистоногие; гельминтозы; энтомофторозы.

Знание закономерностей и причин динамики численности насекомых играет важную роль в прогнозировании массовых размножений вредящих человеку видов. Поскольку примерно $37 \%$ фауны жуков- листоедов (Coleoptera, Chrysomelidae) являются именно вредящими видами, нам представлялось интересным выяснить причины, корректирующие численность данной группы насекомых-фитофагов. 
Павлов С.И., Яицкий А.С., Минияров Ф.Т.

Материал и методика исследований

Материал собран нами в 1974-2016 гг. на территории Самарской области. Были использованы стандартные методики, доработанные нами:

1) изучение климатических параметров среды (особенно их резких «скачков»), лимитирующих численность жуков-листоедов;

2) выявление спектра растений, потребляемых листоедами (нативные наблюдения, изучение трофики в садках (рис. 1) на стационаре), оценка суточной нормы корма и гибели насекомых при бескормице;

3) исследование пресса конкурентов и проявлений каннибализма, при ухудшении условий обитания, на плотность популяции;

4) выяснение влияния хищников, экто- $и$ эндопаразитов на выживаемость насекомых-фитофагов.

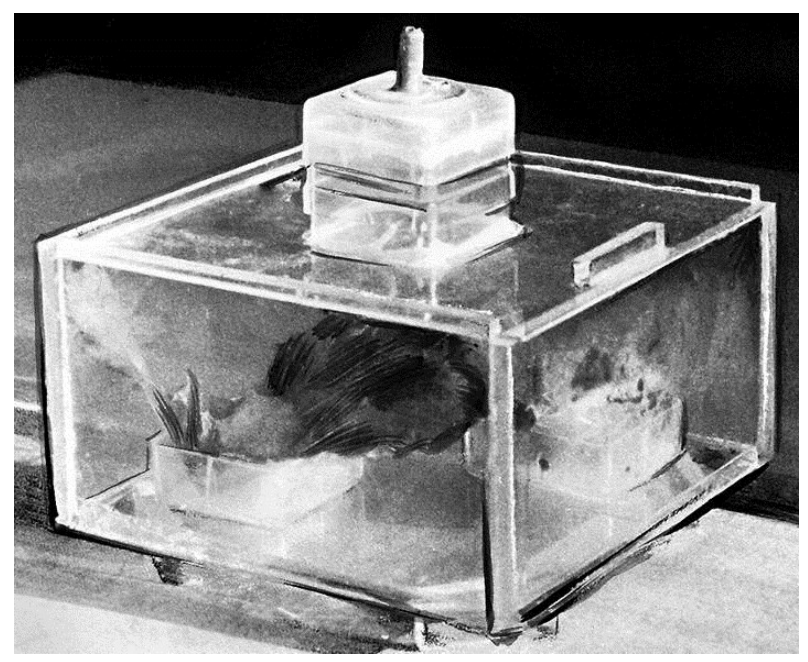

Рисунок 1 - Бокс (конструкции инженера

А.В. Лаврина) для постановки экспериментов по изучению кормовых спектров и реакций жуков-листоедов (фото С.И. Павлова)

Нами обработаны также сборы и фотоматериалы самарских энтомологов: С.А. Китанина, Д.В. Магдеева, В.Н. Макаренкова и В.Ю. Степанова.

\section{обсуждение результатов}

Характеризуя популяцию какого-либо вида, в первую очередь обращают внимание на ее количественные показатели, которые распадаются на 2 составляющих: статические и динамические.

Первая группа характеризует состояние популяции в данный момент времени и включает значения численности, плотности и показатели структуры.

Вторая группа иллюстрирует процессы, идущие внутри популяции за избранный отрезок времени: рождаемость, смертность и скорость роста популяции.

Численность социума не остается неизменной с течением времени. Она сильно зависит от динамики условий окружающей вид среды, которая, в свою очередь, корректирует уровень рождаемости и смертности, часто провоцируя животных (в данном случае насекомых) к длительным миграциям. Соответственно уровень рождаемости и смертности определяется временем достижения организмом половозрелости, реальной плодовитостью особей и продолжительностью генерационного цикла вида.

Продуктивность организма, участвующего в круговороте веществ биосферы, определяется его приспособительными особенностями [1]. Под продуктивностью мы понимаем продолжительность жизни насекомого, сроки его репродуктивной и трофической активности и количество оставленных потомков.

\section{A. Естественный закономерный}

периодический спад численности насекомых

При пространственно-временных флуктуациях, называемых иначе «пульсированием численности», или «популяционными волнами», численность насекомых закономерно меняется. Волна «роста и убыли» численности популяций насекомых выглядит, более или менее, равномерной кривой, хорошо объясняемой с позиции «теории цикличности» [2], где цикличность развития биосферы и составляющих ее компонентов определяется цикличностью и жесткой упорядоченностью природных процессов, напрямую или опосредованно связанных с солнечной активностью (солнечной цикличностью).

Известный философ Ф. Энгельс, рассуждая о взаимоувязанных и зависимых отношениях организмов в биосфере, высказался так: «В природе ничто не совершается обособленно. Каждое явление действует на другое, и наоборот» (изи. по: [1]).

Это единственный случай закономерных и повторяющихся (с интервалом 1 раз в 3, 7 и 11 лет) колебаний состояния популяций.

\section{Б. Абиотические влияния среды обитания}

Комплекс климатических параметров среды (температура и влажность воздуха, ветер и осадки) создает фон, определяющий уровень жизнедеятельности и режимы взаимодействия организмов. Обычно он обладает высокой лабильностью и значительным корректирующим действием на численность насекомых.

1. Холодные и малоснежные зимы, «вылмораживаюшие» зимуюшие фазы насекомых.

Как показали наши наблюдения (2018 г.) за насекомыми, зимующими в садках, даже при средних показателях зимнего сезона (продолжительность его около 125 суток; средняя температура воздуха $-9,9^{\circ} \mathrm{C}$; мощность снежного покрова - от 35 до $40 \mathrm{~cm}$; глубина промерзания почвы - 45-50 cм; количество ветреных дней - около 90; средняя скорость ветровых потоков - 5 км/час), погибает примерно $25 \%$ популяции.

При ужесточении условий перезимовки (например, в соответствии с нашими наблюдениями, продолжительности зимнего сезона 2013 г. - около 150 суток; средней температуре воздуха $-12,4^{\circ} \mathrm{C}$; мощности снежного покрова - от 22 до 26 см; глубине промерзания почвы - 65-80 cм; количестве ветреных дней - около 100; средней скорости ветровых потоков -6 км/час) к моменту выхода из мест зимовки сохраняется только 30-35\% уходивших на зимовку особей (т.е. погибает 65-70\% насекомых).

2. Резкие и продолжительные перепады темпеpamypbl воздуха в момент выхода жуков из мест зимовки, в репродуктивный период и при появлении личинок:

- резкие - с амплитудой около $15^{\circ} \mathrm{C}$ (от -5 до $\left.+10^{\circ} \mathrm{C}\right)$ и продолжительностью в 5-7 суток «рывки» температуры воздуха (при норме в этот фенологический период $+5^{\circ} \mathrm{C}$ ) примерно на $20 \%$ сокращают поголовье имаго, выходящих с мест зимовки;

- резкие - с амплитудой в $12-16^{\circ} \mathrm{C}$ (от $+12 \ldots$ $+14^{\circ} \mathrm{C}$ до $+26 \ldots+28^{\circ} \mathrm{C}$ ) и продолжительностью $3-5$ суток перепады температуры воздуха (при фенологической норме $+20^{\circ} \mathrm{C}$ ) почти на $5 \%$ снижают чис- 
Павлов С.И., Яицкий А.С., Минияров Ф.Т.

Причины сокращения численности насекомых Самарской области..

03.02 .00 - общая биология

ленность имаго-брачных партнеров в репродуктивный период;

- резкие - с амплитудой в $20-24^{\circ} \mathrm{C}($ от $+11 \ldots$ $\ldots+13^{\circ} \mathrm{C}$ до $+33 \ldots+35^{\circ} \mathrm{C}$ ) и продолжительностью в $2-$ 4 суток перепады температуры воздуха (при фенологической норме $+23^{\circ} \mathrm{C}$ ) снижают поголовье только что отродившихся молодых личинок на 27\%.

Это справедливо не только для листоедов, но и большинства других групп насекомых. Например, V.M. Stern и R.F. Smith [3] доказали, что интенсивность яйцекладки бабочек Colias philodice eurytheme зависит в меньшей степени от уровня освещенности, влажности и обеспеченности кормом, чем от температурного режима среды.

3. Гибель насекомых в низинах рельефра, при затоплении их в период половодий и паводков.

Поскольку основная доля резких подъёмов уровня воды (в результате схода талых вод или заполнения низин дождевой водой) наблюдается в весенний и летний периоды и продолжительность их не столь велика (около 5-20 суток), мы использовали данные о выживании имаго колорадского жука при затоплении, пересчитав результаты на долю погибших в воде особей.

Выяснилось, что при пребывании в воде весной в течение 5 суток погибает до $86 \%$ (ослабленных перезимовкой) жуков, присутствие в воде в течение 20 суток, вызывает смерть у 94\% задействованных в экспериментах насекомых.

Присутствие в воде в период летнего паводка в течение 5 суток приводит к гибели 68\% жуков, погружение же на 20 суток, приводит к смерти до $89 \%$ насекомых.

4. Холодные или жаркие сухие летние сезоньл.

Как показали наши наблюдения (2018 г.) за генерацией насекомых в садках (выставленных на стационаре), даже при самых средних показателях летнего периода (продолжительность - 88-95 суток; средняя температура воздуха $+20,4^{\circ} \mathrm{C}$; влажность воздуха 62-65\%; количество ветреных дней - около 48; средняя скорость ветровых потоков - 5 км/час), погибает $14-18 \%$ кладок и личинок.

При ужесточении условий развития преимагинальных (от яйца до куколки) фаз (например, при средней температуре воздуха летнего сезона $+27,2^{\circ} \mathrm{C}$ в 2010 г.; влажности воздуха - 32-35\%; количестве ветреных дней - около 65; средней скорости ветровых потоков - $5 \mathrm{~km} /$ час) погибает в 2 раза больше насекомых, т.е. примерно $35 \%$.

5. Повышенная или пониженная влажность воз$\underline{\partial x x a}$, заметно ослабляющая организм насекомого.

Оптимальная влажность воздуха для развития жука-листоеда, обитающего в средних широтах европейской части России, колеблется в интервале от 45 до 55\%; амплитуда колебания влажности в ту или другую сторону лишь на 10\% (от 35 до 65\%) «переводит» насекомое в область пессимума.

6. Гибель кладок и эмбрионов при избыточном облучении в прямом потоке солнечного света.

По отношению к условиям освещения жуковлистоедов подразделяют на 2 группы: гелиофиль (светолюбы) и умброфиль (теневыносливые виды). Соответственно, по отношению к условиям увлажнения их разделяют на ксерофилов (засухоустойчивые) и мезофилов (влаголюбивые виды).
Предполагая, что более светолюбивые виды, скорее всего, будут проявлять большую терпимость к дефициту влажности (рис. 2.1); и, наоборот, что умброфилы (в силу их тяготения к затененным участкам), вероятно, будут более мезофильными (рис. 2.2), мы выбрали 4 модельных вида (табл. 1).

таблица 1 - Жуки-листоеды с ярко выраженной приуроченностью к разным режимам освещения и влажности

\begin{tabular}{|l|c|c|}
\hline & Гелиофилы & Умброфилы \\
\hline Ксерофилы & $\begin{array}{c}\text { Chrysolina } \\
\text { graminis }\end{array}$ & $\begin{array}{c}\text { Leptinotarsa } \\
\text { decemlineata }\end{array}$ \\
\hline Мезофилы & $\begin{array}{c}\text { Cassida } \\
\text { rubiginosa }\end{array}$ & $\begin{array}{c}\text { Gastrophysa } \\
\text { polygoni }\end{array}$ \\
\hline
\end{tabular}

Искусственно облучая (сериями по 10 яиц) в потоке солнечного света (интенсивностью в 100000 $л \kappa)$, при оптимуме температуры и влажности среды, начиная с 1 мин. до того момента, когда облученные личинки перестали отрождаться, мы установили «критические пороги» допустимой солнечной радиации (табл. 2).

Таблица 2 - Критические пороги облучения кладок жуков-листоедов солнечным светом

\begin{tabular}{|l|c|c|}
\hline & Гелиофилы & Умброфилы \\
\hline Ксерофилы & 20 мин. & 7 мин. \\
\hline Мезофилы & 15 мин. & 5 мин. \\
\hline
\end{tabular}

\section{7. Обильные и частые осадки, смываюшие жуков} и личинок с листьев.

Жуки-листоеды довольно консервативны в выборе места питания, и, в этой связи, избегают лишних, отвлекающих их перемещений в пространстве. Однако случается, что иногда они бывают смыты с листьев вниз внезапно начавшимся сильным дождем.

Во время «пика» репродуктивного процесса, когда жуки компактно группируются в ограниченном секторе кроны, при массовых размножениях (в «очагах» агрегаций), такое «принудительное дождевание» способно унести (исходя из 100\%-го объема популяции насекомых) сразу до $45 \%$ половозрелых имаго.

8. Сильные ветры, сотрясающие растительный субстрат и сбрасывающие личинок вниз.

На долю штилевых дней приходится обычно не более $20 \%$ светлого времени летнего периода (т.е. 15-18 дней из 91 в среднем). Из 80-84\% ветреных дней (т.е. 73-76 - из 91) примерно 30\% приходится на дни со слабыми ветровыми потоками (со скоростью не более 2,5 м/сек, т.е. около 9 км/час), 53\% на долю дней с умеренными ветрами (со скоростью $20 \mathrm{kM} /$ час) и около $17 \%$ - на сильно ветреные дни (со скоростью свыше $30 \mathrm{\kappa m} / \mathrm{uac}$ ).

Разумеется, учесть долю погибших от ветра в естественной природе насекомых невозможно, но наблюдения в садках, высавленных на стационаре, позволяют предположить «отсев» до 5\% особей. 
Павлов С.И., Яицкий А.С., Минияров Ф.Т.

В. Биотические влияния среды обитания:

1. Нестабильность и особенно дефичит кормовой базыl.

Общий объем кормовой базы определяет верхний предел численности насекомых на каждом конкретном участке местности. Однако есть мнение [4], в соответствии с которым численность насекомых может зависеть не от кормовой базы вообще, а только от доступной, в данный момент для популяции, части имеющихся кормовых ресурсов (рис. 2.3). Так, большое значение в распространении листоедов по популяционному ареалу и вертикальным ярусам фитоценоза, а также в их численности имеет фенологическая стадия (рис. 2.4) их кормовых растений [5]. Ученые приводят ряд убедительных примеров, объясняющих значительную смертность в популяциях саранчовых: позднее появление молодых личинок, совпадающее с увяданием и отмиранием основной массы кормовых растений, сопряжено с большим «отсевом» молодых насекомых; кроме того, для молодых личинок, отличающихся малой подвижностью, поиски кормовых растений среди высокого и густого травостоя крайне затруднены и энергоёмки; наконец, обильные весенние дожди, вызывающие бурное развитие травостоя, опять же, губительны для младших возрастов насекомых, поскольку требуют от них некомпенсируемых энергозатрат [5].

В случае же благоприятного расклада, численность листоедов может быть весьма значительной. Так, в результате анализа обилия насекомых в кронах деревьев ольхи клейкой, проведенного чешскими энтомологами [6], было зарегистрировано 4 доминирующих группы, 1/3 (или 33,6\%) из которых составляли жесткокрылые. Причем, 76,7\% приходилось на долю жуков-листоедов, из них численно преобладал ольховый листоед (Agelastica alni). Нативные учеты показали, что весной на $1 \mu^{2}$ поверхности листьев приходилось по 40 особей (т.е. 1 ос. на $250 \mathrm{~cm}^{2}$ ); к концу лета плотность листоедов снижалась до 10 ос. (1 ос. на $1000 \mathrm{~cm}^{2}$ ); в начале осени численность снова поднялась до 37 ос. (1 ос. на $272 \mathrm{~cm}^{2}$ ). В августе (в период максимального спада поголовья жуков) численность ольхового листоеда, тем не менее, местами достигала 91,8 oc. $/ \mathcal{M}^{2}$.

2. Случайный (по разнылм причинам) дефект или гибель кормового растения, в результате чего развивающееся насекомое лишается полноценного питания.

В системе отношений «кормовое растение - потребитель-фитофаг» существует 4 естественных комбинации:

1) корма мало - потребителей мало;

2) корма много - потребителей много;

3) первоначально корма много - потребителей много, но в результате стихийного бедствия (наводнения, засухи, пожара) всего становится очень мало;

4) первоначально корма много - потребителей много, но в результате гибели растения (например, высыхания стебля, сломанного ветром, или растрескивания побега, при дефиците влаги) потребителей остается много, но они голодают.

Последняя ситуация, безусловно, угнетает насекомых, а в ряде случаев и заметно сокращает их численность.
3. Несогласованность (разбалансированность) половой структуры популяции.

В идеале соотношение полов в популяции должно соответствовать пропорции - 1:1. Только у ряда родов в подсемействе Clytrinae существует численный перекос в сторону преобладания самцов.

Но вполне возможна ситуация, при которой количество самцов по какой-то причине может уменьшиться, и, в этом случае, баланс сместится в сторону доминирования самок. Самцы листоедов на начальном этапе периода репродукции часто открыто перемещаются в поисках аттрактивных самок и подвергаются большой опасности (могут быть сброшенными ветром, смытыми дождем или пойманными хищником). Именно этот аспект (разницу в значениях «порогов смертности» самцов и самок) и, по этой причине, смещение соотношения полов в сторону численного перевеса самок (у жужелиц, например, иногда в 2 раза) был подмечен и обстоятельно проанализирован коллективами испанских [7] и шведских [8] энтомологов.

Самки же, в силу их жесткой локализации в месте кормления и сравнительно невысокой мобильности, на этом этапе менее подвержены влияниям негативных факторов среды. Однако, после спаривания, вынашивания эмбрионов и при откладке яиц, они тоже часто рискуют погибнуть. В этом случае, соотношение «склоняется» в сторону перевеса поголовья самцов (рис. 2.5).

4. Несоответствие возрастной структуры популячии, затрудняющее воспроизводство вида.

Поскольку у большинства групп жуков-листоедов разные возрастные фазы (яйцо, личинка, куколка и имаго) «разведены» во времени и почти не встречаются, то речь, в первую очередь, должна идти о соотношении половозрелых жуков, с той лишь разницей - участвовали ли они в брачном процессе или же ни разу не спаривались. Так, по наблюдению бразильских энтомологов [9], набор возрастных и половых групп в популяции сильно различается. Например, если в среднем имаго листоеда-щитоноски Charidotis punctatostriata живут 283,7 $\pm 13,2$ дня, то максимальная продолжительность жизни неспаривавшихся самок (450 дней) превышала таковую (примерно на 50 дней) у спаривавшихся; у неспаривавшихся самцов она почти в 2 раза меньше, чем у спаривавшихся (соответственно примерно 290 и 480 дней).

5. Влияние меж- и внутривидовой конкурениии на плотность популяции жуков того или иного вида.

Скрытно или явно, но в популяции всегда присутствует конкуренция за ресурсы. Межвидовая конкуренция у насекомых (особенно фитофагов) изучена недостаточно, несомненно одно - потребляя избранные части кормового субстрата (листья, корни, соцветия), разные группы насекомых наносят, в той или иной степени, ущерб растению, одновременно «жестко» соперничая друг с другом. Конкуренция между отдельными таксонами жуков-листоедов изучена гораздо лучше [10]. Выявлены растения, наиболее привлекательные для насекомых в качестве кормовых субстратов (например, на листьях ивы способны кормиться, по меньшей мере, 20 видов жуковхризомелид, на листьях дуба летнего - до 15 видов). Для растений с более узким спектром «потребителей» нами были определены конкурирующие «тройки» и «пары» листоедов. 

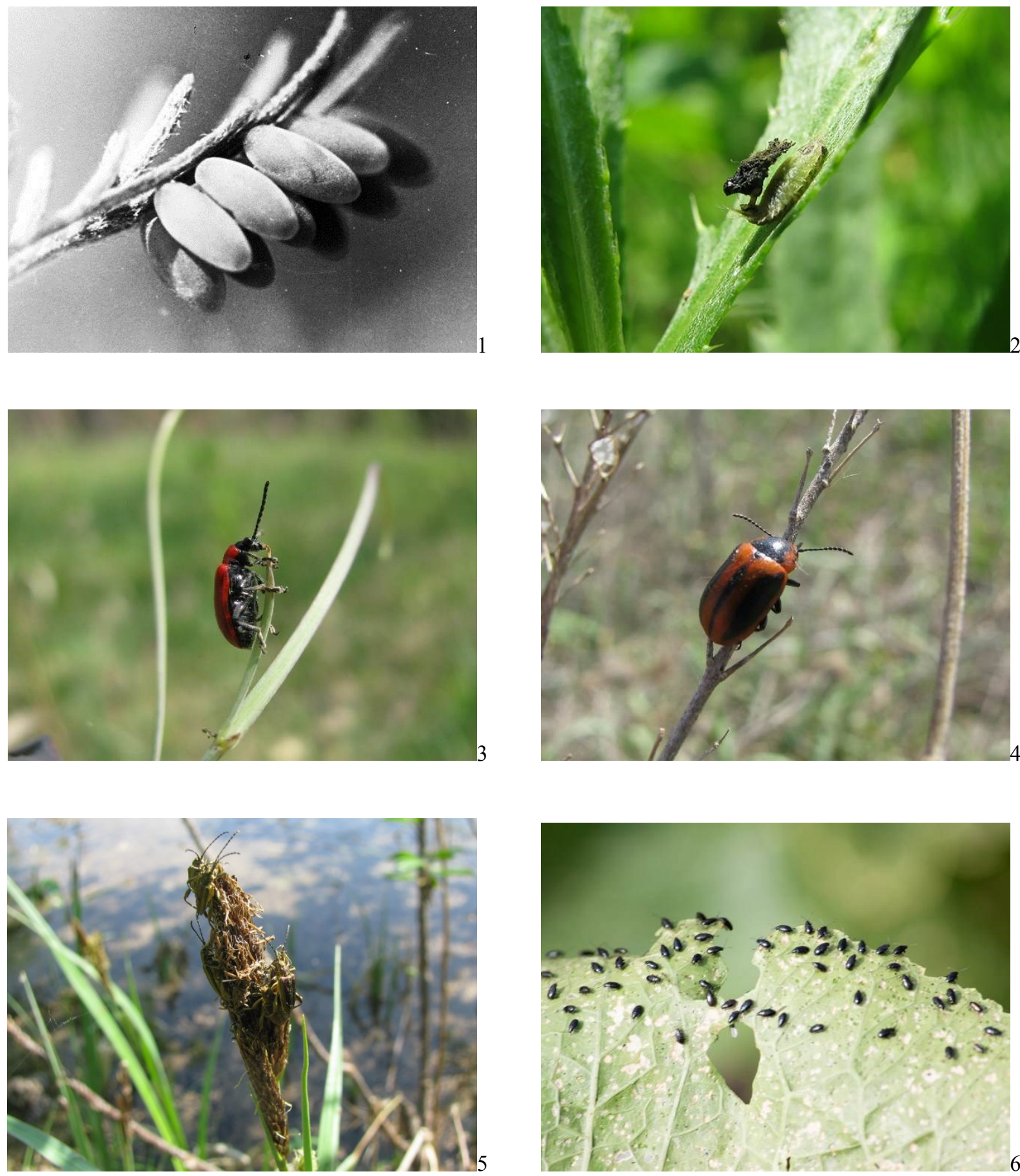

Рисунок 2 - Адаптивное поведение жуков-листоедов.

1 - Самка травяного листоеда Chrysolina graminis подвешивает эмбрионы с нижней стороны узких листьев полыни высокой, защищая их, таким образом, от прямого потока солнечного света (фото С.И. Павлова);

2- Щиток из экзувиев и экскрементов (покоящийся на хвостовых нитях над спиной), как зонт, защищает личинку листоеда-щитоноски от жесткого солнечного излучения (фото В.Н. Макаренкова);

3- Взбираясь на самый верх побега кормового растения, жук Lilioceris lilii высасывает сок и одновременно осматривает окрестности (фото В.Н. Макаренкова);

4- Будучи запрограммированным на потребление только фрагментов кормового растения, рапсовый листоед Entomoscelis adonidis, даже при отсутствии зеленых листьев,

предпочитает долгое время не расставаться с растением-прокормителем (фото В.Н. Макаренкова);

5- Обычно в популяциях листоедов-радужниц (Donaciinae) число самцов равно числу самок,

но, при определенных ситуациях, может возникнуть и диспропорция,

при которой самцов бывает в 2 или 3 раза больше (фото В.Н. Макаренкова);

6- При массовых размножениях число особей жуков-листоедов в скоплениях, например, блошки Phyllotreta atra, может увеличиться в 2 и более раза

(на снимке, например, - на 1 см² поверхности листа хрена кормится в среднем по 4,5 ос.). В это время насекомым приходится жестко конкурировать друг с другом из-за кормового ресурса (фото О.В. Павловой) 

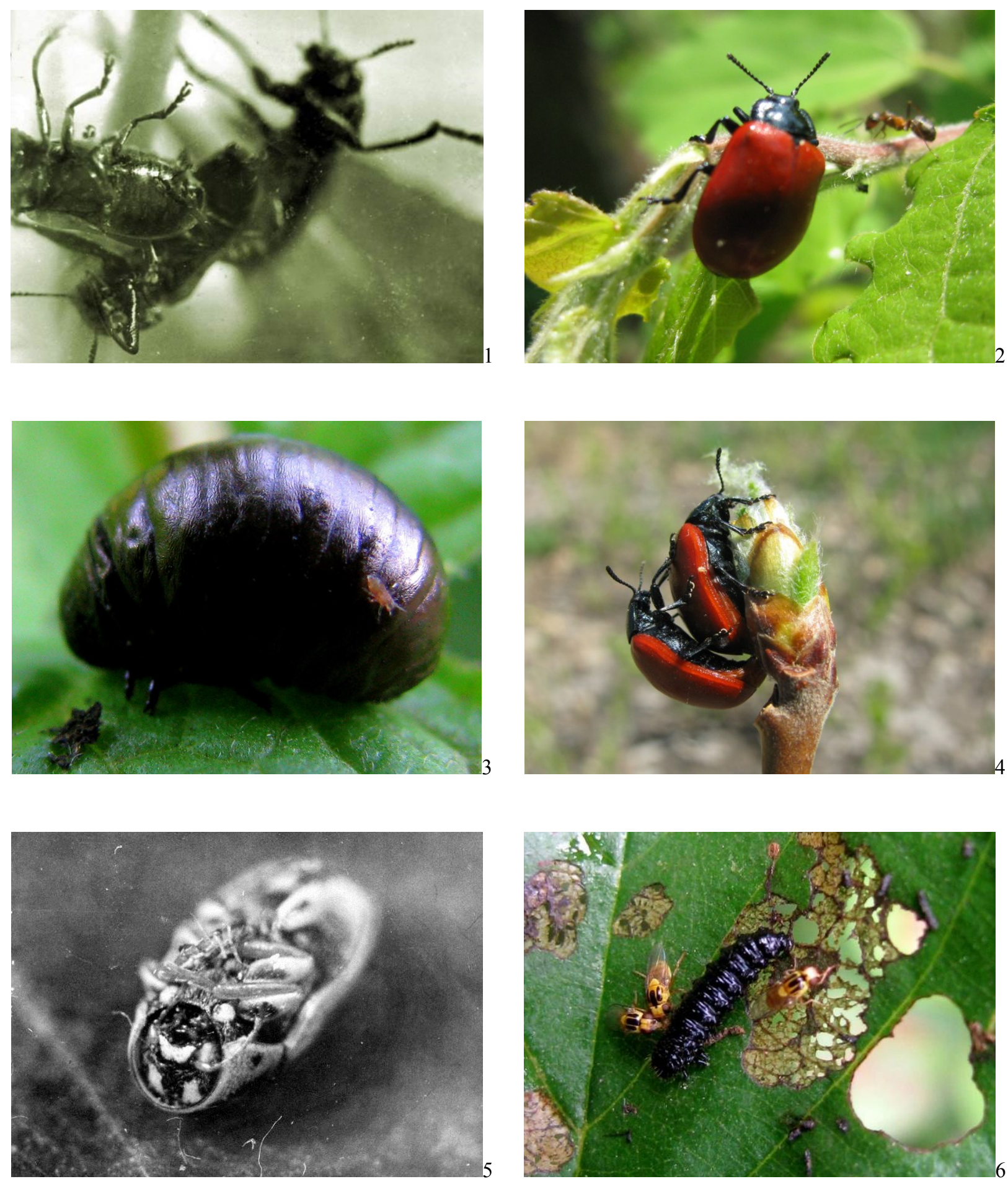

Рисунок 3 - Поведение жуков-листоедов при адаптации к меняющимся условиям среды.

1 - в популяции листоедов Labidostomis, где на каждых 10 самцов приходится примерно 7 самок, между брачными конкурентами часто возникают ожесточенные драки (фото С.И. Павлова); 2 - обычно муравьи нападают на доступную добычу (личинок листоедов),

но случается и агрессия по отношению к довольно крупному жуку Chrysomela populi (фото В.Н. Макаренкова);

3- личинка 3-го возраста листоеда Chrysolina violacea, подвергшаяся нападению клеща

(на снимке - в районе 7-го тергита), сгруппировалась и затаилась. У крупных насекомых не существует механизма защиты от мелких хищников и эктопаразитов (фото О.В. Павловой);

4- клещи нападают даже на жуков (в данном случае на самку тополевого листоеда -

эктопаразит сидит на внешнем крае правой элитры, близ сустава бедра и голени задней ноги), затем прицепившись на брюшке в области шва между соседними стернитами,

они паразитируют на одном хозяине-прокормителе иногда всю свою жизнь (фото В.Н. Макаренкова); 5- погибший желтоватый скрытоглав Cryptocephalus flavicollis

был поражен энтомофторозом (фото С.И. Павлова);

6- личинка козявочки Pyrrhalta viburni и ее «эскорт» - злаковые мушки рода Thaumatomyia из семейства Chloropidae - слизывают сок, вытекающий из поврежденного листа калины (фото В.Н. Макаренкова) 
У большинства групп насекомых-фитофагов (и жуков-листоедов в том числе) внутривидовая конкуренция (чаще всего, за корм или обладание брачным партнером - обычно самкой) хотя и наблюдается довольно локально (рис. 2.6 и 3.1) и с продолжительными интервалами времени, но может иметь заметное ограничивающее значение (т.е. влиять на численность особей в популяции).

6. Каннибализм среди личинок (реже - имаго по отношению к личинкам).

В результате наших экспериментов [11] по изучению кормовых спектров жуков-листоедов, проведенных в лаборатории, были зарегистрированы неоднократные случаи каннибализма у вида Plagiodera versicolora (подобное же мы наблюдали и в природе, но поскольку объективные подсчеты в нативных условиях крайне затруднены, наблюдения были перенесены в искусственную среду).

В 1-й серии опытов, в условиях стесненного пространства, но достаточной обеспеченности кормом, «отсева» насекомых, задействованных в эксперименте, не было зарегистрировано.

Во 2-й серии экспериментов, в оптимальном объеме, но с ограниченными пищевыми ресурсами, личинки 3-го возраста уничтожили около $80 \%$ яиц и до $50 \%$ личинок 1-го возраста. Жуки истребили около $60 \%$ яиц. Но и в случае с взрослыми личинками, и - с имаго поедания куколок мы не регистрировали.

В 3-й серии экспериментов, в ограниченном жизненном пространстве, с минимумом пищевых ресурсов и режимом пониженной влажности, личинки 3 -го возраста уничтожили $100 \%$ яиц, около $80 \%$ личинок 1-го возраста и 70\% куколок. Жуки съели $80 \%$ яиц и личинок 1-го возраста, но не тронули ни одной куколки.

Яйца, личинки младших возрастов, куколки поедались взрослыми личинками и жуками (кроме куколок) в первую очередь при дефиците воды, во вторую - при недостатке корма. Нами было замечено, что использовавшие животные пищевые субстраты личинки и жуки способны голодать дольше (на 2-3 суток), чем после потребления растительного корма. Таким образом, каннибализм взрослых личинок и жуков Plagiodera versicolora следует считать компенсаторным, поскольку он бывает индуцирован резко ухудшившимися условиями обитания.

Подобные экстремальные ситуации в популяциях и вызванные ими вспышки массового каннибализма безусловно способны заметно дестабилизировать численность даже крупных сообществ.

7. Влияние на фитофагов хищных членистоногих (особенно при их массовых размножениях).

Нами было замечено, что личинки младших возрастов жуков-листоедов, особенно агрегированные и малоподвижные, являются удобным кормовым объектом для многих хищников-энтомофагов (преимущественно хортобионтов), таких как пауки - цветочные (Misumena vatia) и волки (Lycosidae), клопыохотники (Nabidae), божьи коровки и их личинки (Coccinellidae), личинки златоглазок (Chrysopidae) и настоящие муравьи (Formicidae). Разумеется, что этот перечень не исчерпывает всех возможных консументов, но эти группы объективно зарегистриро- ваны нами. По обилию «потребителей» хищники распределились примерно так: клопов - $17 \%$, коровок - 26\% (из них: имаго - $11 \%$, личинок $-15 \%$ ), муравьев $-27 \%$ (рис. 3.2 и 3.3 ) и личинок хризоп $-30 \%$.

Установлено [12], что только среди обитающих в Среднем Поволжье хризоп, больше половины (13 видов) является зоофагами, характеризующимися высокой активностью питания.

Анализ [13] гибели жертв разных возрастов показал, что в пределах одной возрастной группы (хищника и жертвы) результативность действий нападающего сохраняется приблизительно на одном уровне (около 34\% успешных атак). При нападении взрослой (3-го возраста) личинки златоглазки на личинок листоедов-щитоносок (способных активно защищаться) гибнет 96\% личинок-листоедов 1-го возраста, $57 \%$ личинок 2-го возраста, $23 \%$ личинок 3 -го возраста. Соответственно, при нападении взрослой (3-го возраста) личинки златоглазки на личинок 3-го возраста листоедов Chrysolina populi L. доля жертв составляет уже около $70 \%$.

При массовых размножениях энтомофагов, их численность возрастает в 2 и более раза, что вызывает резкое «угнетение» популяций насекомых-фитофагов (и, в том числе, жуков-листоедов).

8. Влияние яйчевых паразитов на развитие молодых эмбрионов, личинок и взрослых насекомых.

На стадии яйца основная регулирующая поголовье листоедов роль принадлежит паразитам.

Гибель личинок часто вызывается поражением их наездниками Pleromalus sp. и Eurytoma sp. [14]. По нашим наблюдениям, при нападении наездников, «отсев» личинок жуков-листоедов (особенно взрослых) может составлять до $20 \%$.

В течение 6 летних сезонов на полях озимого и ярового рапса в период цветения и плодоношения растений было собрано [15] около 70 видов наездников (принадлежащих к 38 родам). Выявлено 5 биологических групп и, в том числе, паразиты жуков, среди жертв которых регистрировалась весьма многочисленная рапсовая блошка (Psylliodes chrysocephalus L.). Исследователем делается вывод, что «из собранных наездников только виды рода Isurgus, повидимому, играют важную роль в уменьшении численности вредящих насекомых».

Кроме того, паразитоидом листоедов является муха-тахина Celatoria compressa [16]. Развиваясь в организме единственного хозяина-прокормителя в течение значительной части своей жизни (в стадии личинки), она в процессе поедания живых тканей постепенно убивает хозяина. Взрослая личинка паразитоида в сухую погоду окукливается в полости тела (где сформировалась довольно вместительная камера) погибшего и уже отвердевшего тела хозяина, во влажную - выйдя наружу, под трупиком прокормителя, прячась в его тени.

По нашим нативным наблюдениям, около $2 \%$ популяции листоедов бывает поражено паразитоидами.

K. Riritani с соавт. [17] считают, что зараженность личинок (в случае с цикадками - нимф) и имаго цикадки Nephotettix cinctipes двукрылыми паразитами (из семейства Dorylidae) действует как фактор, замедленно зависимый от плотности популяции (чем 
Павлов С.И., Яицкий А.С., Минияров Ф.Т.

плотнее популяция, тем большее количество насекомых-«хозяев» заражается паразитами).

При низкой численности нимф, она регулируется охотничьей активностью пауков [17].

9. Эктопаразиты (клещи) личинок и имаго.

Эктопаразиты (рис. 3.4) сами по себе способны «угнетать» хозяев-прокормителей, питаясь их гемолимфой и соками внутренней среды организма. Довольно часто на одном жуке или личинке может паразитировать до 10-20 клещей или их нимф. Кроме того, они часто являются переносчиками болезней, яиц гельминтов и спор паразитических грибов.

Клещ Blattisocius tarsalis, обладающий довольно широкой «трофической валентностью», стал [18] основным регулятором численности яиц и молодых гусениц в популяциях бабочки-огневки Anagasta kühniella.

10. Заражение насекомых спорами энтомофторовых грибов (особенно активно происходящее на фоне повышенной влажности воздуха), что приводит к массовой гибели насекомых (рис. 3.5).

Энтомофторовые грибы встречаются в самых разнообразных местах, но обычно хорошо развиваются там, где имеется постоянный источник влаги (тенистые низины, берега ручьев и прудов).

«Некоторые виды семейства Entomophthoraceae, считают В.И. Полтев и соавт. [19], - поражает большой круг хозяев (даже из различных отрядов), другие живут только на насекомых одного вида или близко родственной группы». Ёмкость зарегистрированного спектра «хозяев» простирается почти до 140 видов (в, том числе, в Евразии - более 60 и в Северной Америке до 70 видов).

Возникновение заболевания в популяции жуковлистоедов Chrysolina populi связано с заметным увеличением относительной влажности воздуха. Изменение температуры среды существенно не влияет на начало эпизоотии, но жестко корректирует биологию и распространение патогенна [20]. Благоприятными для развития и роста гриба условиями [21] является температура в интервале от $+18^{\circ} \mathrm{C}$ до $+28^{\circ} \mathrm{C}$ и относительная влажность, превышающая $60 \%$.

11. Болезни и гельминтозы, развиваюшиеся в популячии, и пути их распространения.

Трансмиссивные (сквозные, или переносимые эктопаразитами на хозяев-прокормителей и своих комменсалов) заболевания обычно не убивают жертв (или насекомых-контактеров), но заметно ослабляют их организм, практически «готовя почву» к их поражению другими агентами окружающей среды.

Так, при облигатно-трансмиссивной (т.е. специфической) передаче возбудителя болезни, например клещом, паразит (точнее, определенная фаза его генерации из слюны переносчика - клеща) попадает в гемолимфу насекомого, где развивается в течение требуемого для этого периода времени.

При факультативно-трансмиссивной (т.е. неспецифической, а, в основном, механической) передаче паразита, например, злаковые мушки (рис. 3.6), слизывая сок, вытекающий из повреждения листа растения, попутно переносят на лапках яйца гельминтов, которые, вполне, могут быть заглоченными жукамилистоедами во время их питания.
12. Микробиота личинок, создающая условия для параллельной инвазии и гибели листоедов.

Микробиота личинок жуков-листоедов представлена, главным образом, бактериями. Исследования В.П. Приставко [22] личинок колорадского жука ( $\mathrm{Le}$ ptinotarsa decemlineata) позволили выделить 31 вид бактерий, а грибы из рода Beauveria.

Выяснилось [22], что пребывание потенциальнопатогенных микроорганизмов в кишечном тракте насекомого не оказывает негативного влияния на его организм. Даже при искусственном введении пероральным способом (т.е. при обычном скармливании) личинкам больших масс патогенов, насекомые продолжают вести нормальный образ жизни.

Установлено [23], что под влиянием даже небольших доз инсектицидов (присутствующих в корме и окружающей среде), происходит активное изменение $\mathrm{pH}$ гемолимфы личинки, в результате чего ее кишечная микробиота выплескивается в полость тела (во внутреннюю среду организма), где, взаимодействуя с гемолимфой, микроорганизмы (Aerobacter aerogenes, Serratia marcescens, Pseudomonas septica, P.fluorescens, Bacillus cereus и особенно Beauveria bassiana) активно размножаются, вызывая гибель организма хозяина.

Подобный же эффект [23] дает парентеральное (минуя кишечник) введение микродоз инсектицида непосредственно в гемолимфу личинки.

Изменение $\mathrm{pH}$ гемолимфы и контакт последней с кишечной микробиотой (комплексом разных видов бактерий) является мощнейшим фактором стремительного ослабления организма насекомого (вплоть до гибели).

\section{Г. Прямое или косвенное \\ уничтожение насекомых человеком \\ (особенно видов, вредящих \\ сельскому и лесному хозяйству)}

Вероятно, это - единственная сфера, где учесть долю истребленных вредителей особенно трудно не только в пределах целой области или района, но даже в границах одного небольшого дачного массива. Можно утверждать определённо, что даже на одном дачном участке уничтожить насекомых полностью (на 100\%) невозможно.

$B$ заключение следует отметить, что изучение общей «убыли» поголовья популяций жуков-листоедов (как, впрочем, и других насекомых-фитофагов) затруднено в связи со следующими обстоятельствами:

- во-первых, отдельные факторы не действуют последовательно, один за другим, а часто влияют одновременно и с максимальной интенсивностью;

- во-вторых, значение отдельных факторов может меняться в разных местообитаниях, например, с приближением к периферии ареала (где популяции распределены мозаично и в значительной степени ослаблены) заметно возрастает роль дестабилизирующих факторов среды вплоть до исчезновения подобных локальных популяций;

- в-третьих, любая популяция не остается «свободной от коррекции» внешней среды - выход ее изпод контроля одного механизма регуляции тут же вызывает автоматическое «включение» следующего фактора-регулятора. 


\section{Список литературы:}

1. Банников А.Г., Рустамов А.К. Охрана природы. Справочник. М.: Колос, 1972. С. 185-187.

2. Белецкий Е.Н. Теория цикличности динамики популяций // Известия Харьковского энтомологического общества. 1993. № 1. С. 5-16.

3. Stern V.M., Smith R.F. Factors affecting egg production and oviposition in populations of Colias philodice eurytheme Boisduval (Lepidoptera, Pieridae) // Hilgardia. 1960. Vol. 29, № 10. P. 411-454.

4. Richards O.W., Southwood T.R.E. The abundance of insects: introduction // Insect Abundance. OxfordEdinburgh. Blackwell Scient. Publs, 1968. P. 1-7.

5. Clark D.P. A population study of Phaulacridium vittatum Sjöst (Acrididae) // Australian Journal of Zoology. 1967. Vol. 15, № 4. P. 799-672.

6. Majzl O. Biomasa článkonožcov (Arthropoda) olisten korún jelše lepkavej - Almus glutinosa (L.) - so zri om na rad Coleoptera // Biologia (ČSSR). 1979. Vol. 34, № 8. P. 607-615.

7. Estever A., López R.M.L., Schnack J.A. Ciclo anual, lecundidad y proporcion de sexos de una poblacion de Pelocoris (P.) binotulatus nigriculus Berg (Hemiptera, Limnocoridae) // Limnobios. 1989. Vol. 2. № 10. P. 729-732.

8. Ericson D. Distribution, activity and density of some Carabidae (Coleoptera) in winter wheat fields // Pedobiologia. 1978. Vol. 18, № 3. P. 202-217.

9. Garcia M.A., Paleari L.M. Ciclo de vida e potencial de crescimento populacional de Charidotis punctatostriata (Coleoptera, Chrysomelidae, Cassidinae) em laboratorio // Revista Brasileira de Entomologia. 1993. Vol. 37, № 2. P. 329-334.

10. Медведев Л.Н., Рогинская Е.Я. Каталог кормовых растений жуков-листоедов СССР. М.: Наука, 1988. С. 23-44.

11. Павлов С.И. Каннибализм как адекватная реакция животных на ухудшение условий обитания // Проблемы современной биологии: мат-лы 8-й междунар. науч.-практ. конф. (15.04.2013, Москва). М.: Изд-во «Спутник+», 2013. С. 51-56.

12. Ковригина А.М. Биология златоглазок ( $\mathrm{Neu}-$ roptera, Chrysopidae) Среднего Поволжья // Исследования энтомофауны Среднего Поволжья: межвуз. сб. науч. ст. Куйбышев: КГПИ, 1980. С. 22-25.

13. Павлов С.И. О разнице в стратегиях личинок щитоносок и их хищников // Проблемы современной биологии: мат-лы 6-й междунар. науч.-практ. конф. (15.10.2012, Москва). М.: Изд-во «Спутник+», 2012. C. 53-60.

14. Hanson P.E. Biology of Janus rufiventris (Hymenoptera: Cephidae) // Annals of the Entomological Society of America. 1986. Vol. 79, № 3. P. 488-490.

15. Miczulski B. Blonkowki (Hymenoptera) w biocenozie upraw rzepaku. Cz. II. Gasieniczniki (Ichneumonidae) // Polskie Pismo Entomologiczne. 1966. Ser. B, № 3-4. P. 263-292.

16. Eben A., Barbercheck M.E. Field observations on host plant associations tntmies of diabroticite beetles (Chrysomelidae; Luperini) in Veracruz, Mexico // Acta Zoologica Mexicana. 1996. № 67. P. 47-65.

17. Kiritani K., Hokyo N., Sasaba T., Nakasuji F. Studies on population dynamics of the green rice leafhopper, Nephotettix cinctipes Uhler: regulatory mechanism of the population density // Researches on Population Ecology. 1970. Vol. 12, № 2. P. 137-153.

18. White E.G., Huffaker C.B. Regulatory processes and population cyclicity in laboratory populations of Anagasta kühniella (Zeller) (Lepidoptera: Phycitidae). 1. Competition for food and predation // Researches on Population Ecology. 1969. Vol. 11, № 1. P. 57-83.

19. Полтев В.И., Гриценко И.Н., Егорова А.И., Кальвиш Т.К., Туркевич Л.Л., Ушакова Н.В. Микрофлора насекомых. Новосибирск: Наука СО, 1969. C. 109.

20. Басова Л.П. Энтомофтороз зеленой яблоневой тли в Куйбышевской области // Вопросы зоологии: Ученые записки. Вып. 83. Куйбышев: КГПИ, 1970. C. 31-35.

21. Басова Л.П. Энтомофторовые грибы - паразиты насекомых в Куйбышевской области // Материалы итоговой научной конф. Март 1970. Биологохимический ф-т. Куйбышев: КГПИ, 1970. С. 18-19.

22. Приставко В.П. К познанию микрофлоры личинок колорадского жука Leptinotarsa decemlineata Say. (Coleoptera, Chrysomelidae) // Энтомол. обозрение. 1966. Т. 45, № 2. С. 302-312.

23. Приставко В.П. Изменение микрофлоры и $\mathrm{pH}$ гемолимфы личинок колорадского жука под влиянием гриба белой мускардины (Beauveria bassiana (Bals.) Vuill.) и ДДТ // Защита растений: респ. межвед. темат. науч. сб. Вып. 4. Киев: Урожай, 1967. С. $47-59$.

\section{REASONS FOR THE NUMBER OF INSECTS DECREASE OF THE SAMARA REGION (ON THE EXAMPLE OF LEAF BEETLE POPULATIONS)}

(C) 2019

Pavlov Sergey Ivanovich, candidate of biological sciences, associate professor of Biology, Ecology and Methods of Teaching Department

Yaitsky Andrey Stepanovich, senior lecturer of Chair of Biology, Ecology and Methods of Teaching Samara State University of Social Sciences and Education (Samara, Russian Federation)

Miniyarov Farit Talgatovich, candidate of biological sciences, associate professor of Biotechnology, Zoology and Aquaculture Department, head of Experimental Zoology Laboratory Astrakhan State University (Astrakhan, Russian Federation)

Abstract. The survival mechanisms of leaf beetles (as typical phytophagous insects, surrounded by a «corrosive environment»: unstable, rapidly changing climate, «decreasing» forage, direct action of predators, ecto- and endoparasites, parasitoids, pathogens helminthiasis and entomophtorous, other pathogenic organisms) were studied during 1974-2016 in the Samara Region. 25 background species of chrysomelid beetles (approximately 240 individuals) were used as «model» objects. In addition to the natural fluctuations of the insect population, 21 causes of sudden increase in the number of local populations of leaf beetles were revealed, as a result of the influence of negative envi- 
Павлов С.И., Яицкий А.С., Минияров Ф.Т.

ronmental agents, including abiotic (8), biotic (12) and anthropic (1 reason). From $5 \%$ to $90 \%$ of the leaf beetles population die as a result of unfavorable wintering conditions, sharp fluctuations in temperature and humidity, wind and precipitation; 2 reasons (concerning the resources of the forage base), 2 reasons (caused by the imbalance of the age and sexual structure of the population and therefore low reproductive potential), 2 reasons (determined by the fierce competition of insects and larval cannibalism) and 6 reasons (associated with the influence of predators, parasites and pathogens) are able to «withdraw» from $2 \%$ to $96 \%$ of the livestock (eggs, larvae, pupae and adults) of the population. It is concluded that many agents affects the number of insects.

Keywords: Samara Region; leaf; leaf-beetles; insects; fluctuations in population size; natural fluctuations in population size; irregular fluctuations in population size; abiotic factors; biotic factors; anthropogenic factors; efficiency; parasitic arthropods; helminths; entomophtorous.

УДК 631.4:551.8

DOI 10.24411/2309-4370-2019-12109

Статья поступила в редакцию 07.02.2019

\section{МЫШЬЯК И СЕЛЕН В БЕРЕГОВЫХ ПОЧВАХ И ДОННЫХ ОТЛОЖЕНИЯХ ПРУДОВ ГОРОДА САМАРЫ}

Прохорова Наталья Владимировна, доктор биологических наук, профессор кафедры экологии, ботаники и охраны природы

Макарова Юлия Владимировна, кандидат биологических наук, доцент кафедры экологии, ботаники и охраны природы

Бугров Сергей Вячеславович, аспирант кафедры экологии, ботаники и охраны природы

Герасимов Юрий Леонидович, кандидат биологических наук, доцент, заведующий кафедрой зоологии, генетики и общей экологии

Платонов Игорь Артемьевич, доктор технических наук, профессор, заведующий кафедрой химии Горюнов Максим Глебович, инженер кафедры химии

Самарский национальный исследовательский университет имени академика С.П. Королёва (2. Самара, Российская Федерация)

Аннотация. Мышьяк и селен включены в группу химических элементов первого класса опасности, что обусловливает необходимость анализа их содержания в природных средах естественных и техногенных экосистем при эколого-биогеохимическом мониторинге. По своим химическим свойствам мышьяк и селен являются металлоидами, или полуметаллами. В очень малых концентрациях они необходимы для нормального функционирования организмов, но при повышении концентраций в среде обитания или продуктах питания проявляют высокую токсичность. Особенно большую опасность представляет накопление мышьяка и селена в аккумулятивных средах и ландшафтах, к которым относятся почвы и замкнутые водоемы. Для урбоэкосистем Самарской области мониторинг содержания мышьяка и селена в компонентах их аккумулятивных ландшафтов ранее не проводился, что подтверждает актуальность и практическую значимость представленных материалов. Авторами были осуществлены эколого-геохимические исследования накопления мышьяка и селена в береговых почвах и донных отложениях двадцати прудов, расположенных в г. Самаре в пределах берегового склона Саратовского водохранилища (Волжского склона) и на водоразделе между Саратовским водохранилищем и р. Самарой. Анализ полученных результатов показал относительно низкий уровень накопления мышьяка в анализируемых субстратах всех изученных прудов. По сравнению с уровнем регионального фона для Среднего Поволжья, изученные аккумулятивные акваландшафты заметно обогащены селеном (в 2-15 раз). Техногенное поступление мышьяка и селена в аккумулятивные ландшафты г. Самары может быть связано с деятельностью металлообрабатывающих и машиностроительных предприятий, а также ТЭЦ. Представленные в статье материалы о содержании мышьяка и селена в береговых почвах и донных отложениях городских прудов г. Самары можно считать пионерными для региона и в дальнейшем использовать в эколого-геохимическом мониторинге региональных урбоэкосистем.

Ключевые слова: пруды; береговые почвы; донные отложения; урбоэкосистемы; мышьяк; селен; тяжелые металлы; металлоиды; эколого-геохимический мониторинг; класс опасности; региональная фоновая концентрация; токсичность химических элементов; изолинейное картирование; город Самара; Самарская область.

\section{Введение}

Современная урбанизация сопровождается резким ростом загрязнения природных сред городов тяжелыми металлами и металлоидами (полуметаллами) [1]. Источники полиметаллического загрязнения в городах многообразны, а их негативное воздействие особенно остро проявляется в отношении почвы, являющейся основным геохимическим барьером урбоэкосистем. Почва непосредственно контактирует с воздухом, принимая участие в регулировании газового состава атмосферы, служит фильтром, очища- ющим поверхностные стоки от загрязняющих веществ, а также экраном, осаждающим и удерживающим атмосферные поллютанты. При этом она становится источником вторичного загрязнения водной и воздушной сред города, что создает угрозу нормальной жизнедеятельности организмов, включая человека $[1 ; 2]$. Максимальное количество тяжелых металлов и металлоидов накапливается в придорожных зонах и в аккумулятивных ландшафтах, к которым относятся замкнутые водоемы, в частности, искусственные пруды. 